\title{
Reaction of Selected Cultivars of Sugar Maple to Anthracnose in North Alabama
}

\begin{abstract}
A. K. Hagan and K. L. Bowen, Department of Entomology and Plant Pathology, Auburn University, Auburn, AL 36849; K. N. Conner, Alabama Cooperative Extension System, Auburn University, Auburn, AL 36849; J. L. Sibley, Department of Horticulture, Auburn University, Auburn, AL 36849; and A. W. Caylor, North Alabama Horticulture Research Center, Cullman, AL 35055
\end{abstract}

Accepted for publication 28 November 2016.

\section{ABSTRACT}

Anthracnose, caused by the fungus Discula campestris, appeared in a planting of 18 sugar maple cultivars in Cullman, AL (USDA Hardiness Zone 7a). Sizable differences in the timing of disease onset and intensification were noted between sugar maple cultivars. On susceptible cultivars, the appearance of reddishbrown lesions 4 to $10 \mathrm{~mm}$ in diameter, sometimes with a tan center and yellow border, in June was followed with the initiation of premature defoliation by mid-July. By early fall, the susceptible cultivars Goldspire, Seneca Chief, and Sugar Queen along with the moderately susceptible cultivars Endowment, Fairview, Flax Mill Majesty, Morton, and Sweet Shadow were defoliated and showed

\section{INTRODUCTION}

Sugar maple (Acer saccharum Marsh.), which are highly valued landscape trees due to their brilliant fall color display, deeply furrowed bark, and attractive growth habit, have relatively few pest and disease issues (Dirr 1998). While sugar maple is commonly associated with deciduous forests of the Northeast and the Upper Midwest (Godman et al. 1990), this widely adapted tree is also a member of an undisturbed tree community in the Sipsey Wilderness in northwest Alabama (Zhang et al. 1999) and is commonly used as a specimen tree in landscapes across the Mid- and Upper South (Dirr 1998). On the basis of growth rate, selected foliage characteristics, and tolerance to Japanese beetle (Popillia japonica Newman) feeding injury, Autumn Blush, Bonfire, Green Mountain, and Sugar Queen were noted as the best-performing sugar maple cultivars in a north-central Alabama planting evaluated between 2001 and 2005 (Blackwood 2006).

Anthracnose, which is incited by multiple conidial fungi in the order Diaporthales (Sinclair and Lyon 2005), can reduce the aesthetic value and possibly the vigor of sugar maple (Hartman 1996). In 2011, an outbreak of anthracnose, which was caused by the fungus Discula campestris (Pass.) Arx [syn. Apiognomonia errabunda (Roberge ex Desm.) Höhn)] (Sogonov et al. 2007), was observed in a planting of 18 sugar maple cultivars in Cullman, Alabama (A. K. Hagan, personal observation). Previously, D. campestris was cited as the causal agent for damaging anthracnose outbreaks in sugar maple in Pennsylvania and New York, along with several New England and Midwestern states (Nash et al. 1994; Stanosz 1994), and Ontario, Canada (Howse and Applejohn 1990). Outbreaks of the D. campestris-incited anthracnose in

Corresponding author: Austin Hagan. Email: haganak@auburn.edu.

doi:10.1094/PHP-RS-16-0047

(C) 2016 The American Phytopathological Society no fall color. In contrast, disease onset was delayed, the level of premature defoliation greatly reduced, and fall color display unaffected on the anthracnose resistant cultivars Autumn Blush, Autumn Faith, Fall Fiesta, and Legacy, all of which would be excellent choices for amenity and commercial landscapes in the Mid- and Upper South. Among the representative cultivars of the four resistance classes, total rainfall and mean temperature influenced premature anthracnose-induced defoliation on the susceptible Sugar Queen and moderately resistant Commemoration, but not on the resistant Fall Fiesta or the moderately susceptible Flax Mill Majesty sugar maples.

Pennsylvania, in association with pear thrips [Taeniothrips inconsequens Uzel] feeding injury, was linked with sugar maple seedling mortality (Stanosz 1993) and damage to the leaves of mature trees (Nash et al. 1994).

At the site of the previous Alabama study (Blackwood 2006), anthracnose symptoms were characterized by the appearance of randomly distributed reddish-brown circular to irregular lesions, 4 to $10 \mathrm{~mm}$ in diameter, sometimes with a tan center and yellow border, independent of the veins on only mature leaves (Fig. 1A). Lesion coalescence on leaves of some cultivars such as Sugar Queen resulted in the formation of large, reddish-brown, necrotic blotches with irregular to angular borders centered along major veins (Fig. 1B). Premature defoliation began on susceptible cultivars within a month of disease onset in mid- to late June. Anthracnose intensification continued into early fall until some cultivars were completely defoliated, thereby eliminating any fall color display (Fig. 1C). The objective of this study was to assess the reaction of a selection of sugar maple cultivars, maintained in a simulated landscape setting in North Alabama, to anthracnose incited by Discula campestris.

\section{SUGAR MAPLE MANAGEMENT AND ANTHRACNOSE ASSESSMENT}

Sugar maple cultivars were established in 2001 at the North Alabama Horticulture Research Center in Cullman, AL (USDA Hardiness Zone $7 \mathrm{a} ; 34^{\circ} 11^{\prime} 12 \mathrm{~N}$; $84^{\circ} 47^{\prime} 50 \mathrm{~S}$; elev. $253 \mathrm{~m}$ ) in a Hartselle fine sandy loam (fine, kaolinitic, thermic Rhodic Paleudults) ( $<1 \%$ organic matter) on $6.1-\mathrm{m}$ centers on rows spaced $6.1 \mathrm{~m}$ apart. Prior to planting, soil fertility was adjusted according to the results of a soil fertility assay conducted by the Auburn University Soil Testing Laboratory. While $1 \mathrm{~kg}(0.34 \mathrm{~kg}$ of actual $\mathrm{N}$ ) of ammonium nitrate $(34 \mathrm{~N}-0-0)$ per tree was broadcast annually from 2001 until 2010, no supplemental fertilizers were applied during the 2012 to 2014 study period. Centipede- 
grass (Eremochloa ophiuroides Munro) alleys were periodically mowed. No supplemental irrigation was provided nor were there any herbicides applications. Anthracnose intensity was assessed on 15 June, 11 August, 15 September, and 18 October 2012; 23 May, 15 June, 19 July, 18 August, and 14 September 2013; and 14 May, 20 June, 15 July, 23 August, and 14 September 2014 using a 1-to-10 scoring system where: $1=$ no disease; $2=$ very few lesions in canopy; 3 = few lesions noticed in lower and upper canopy; $4=$ some lesions seen and $\leq 10 \%$ defoliation; $5=$ lesions noticeable and $\leq 25 \%$ defoliation; $6=$ lesions numerous and $\leq 50 \%$ defoliation; 7 = lesions very numerous and $\leq 75 \%$ defoliation; $8=$ numerous lesions on few remaining leaves and $\leq 90 \%$ defoliation; $9=$ very few remaining leaves covered with lesions and $\leq 95 \%$ defoliation; and $10=$ plants defoliated (Chiteka et al. 1988). Defoliation values were calculated using the modified formula:

$\%$ defoliation $=100 /\left(1+\mathrm{e}^{-[(\text {Anthracnose intensity score }-6.0672) / 0.7975]}\right)$

(Li et al. 2012). Areas under disease progress curves (AUCs) were calculated for anthracnose intensity (AAUC) and defoliation (DAUC) scores for each tree in each study year (Shaner and Finney 1977). Intensity and defoliation AUCs were divided by the number of days over which observations were made in each year: 125 days in 2012; 136 days in 2013; and 152 days in 2014 to generate "relative (r) AUC" values, which allows direct comparisons of each variable over years. These rAUCs within each year were checked for normality; non-normal data were rank-transformed for analysis and back-transformed for presentation. Mixed model analyses were done on rAAUC and rDAUC with cultivar as the fixed effect and year*rep as random effect (Proc GLIMMIX in SAS 9.3; SAS Institute Inc., Cary, NC). Differences in rAAUC and rDAUC among cultivars were considered significant when $P$ $\leq 0.05$.

\section{WEATHER}

Daily temperature and rainfall were recorded by and collected from an AL Mesonet weather station located at the North Alabama Horticulture Research Center in Cullman, AL. The trees were located within $1000 \mathrm{~m}$ of this weather station. From these data, average monthly temperatures from 1 May to 31 September and total monthly rainfall in each study year were calculated. Due to equipment failures, however, several days of weather records for August 2013 were lost.

\section{SUGAR MAPLE CULTIVAR REACTION TO ANTHRACNOSE}

Anthracnose intensity (rAAUC) and defoliation (rDAUC) differed significantly by sugar maple cultivar $(P<0.0001)$. The resistant $(\mathrm{R})$ and susceptible $(\mathrm{S})$ classifications were delineated by differences in defoliation rDAUC values and well supported by intensity rAAUC values, while the moderately resistant (MR) and moderately susceptible (MS) classifications were based on a combined assessment of rAAUC and rDAUC values.

The sugar maple cultivars Fall Fiesta, Commemoration, Flax Mill Majesty, and Sugar Queen represent the resistant, moderately resistant, moderately susceptible, and susceptible cultivars, respectively (Table 1). In addition to Fall Fiesta, the cultivars Autumn Blush, Autumn Faith, and Legacy were classified as anthracnose resistant, although some overlap in Autumn Faith rAAUC intensity values with several moderately resistant cultivars was noted.

Among the moderately resistant cultivars, Green Mountain had a lower rAAUC intensity value but a similar rDAUC defoliation value as Apollo, while Steeple and Wright Brothers had a lower rDAUC defoliation value than Bonfire (Table 1). While Apollo rAAUC intensity was greater than Commemoration, Steeple, Wright Brothers and Green Mountain, the observed defoliation on this cultivar was similar to the other moderately resistant cultivars except for Steeple.

With the exception of the rAAUC and rDAUC for Apollo and Bonfire, respectively, anthracnose intensity and defoliation was higher for the moderately susceptible than the remaining moderately resistant cultivars (Table 1). Fairview had a higher rAAUC intensity value than the other moderately susceptible cultivars except for Flax Mill Majesty, which along with Morton, Endowment, and Sweet Shadow had similar lower rAAUC intensity values. Sweet Shadow suffered greater defoliation than Morton and Endowment. Defoliation levels were also greater for Flax Mill Majesty than Morton. Sugar Queen, Seneca Chief, and

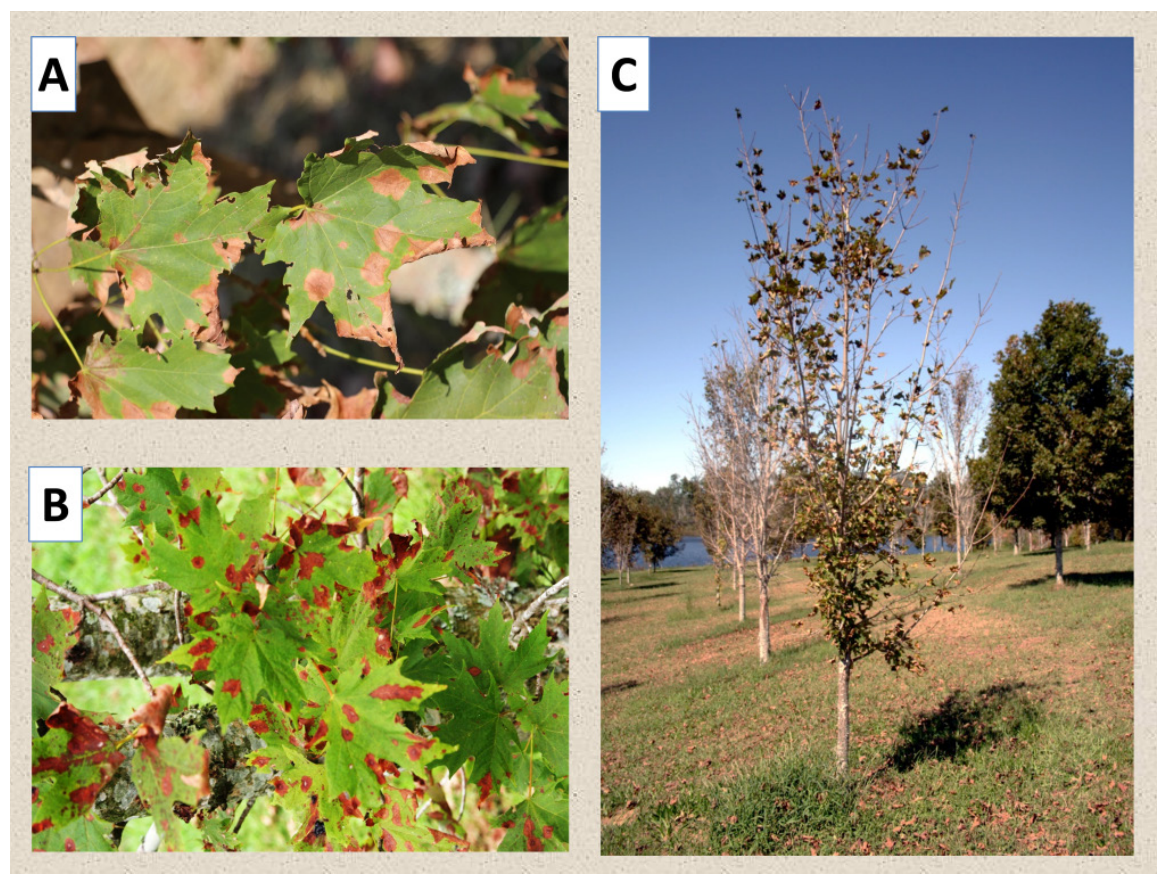

\section{FIGURE 1}

Anthracnose symptoms on (A) Apollo and (B) Sugar Queen sugar maple along with $(\mathbf{C})$ premature defoliation on Fairview sugar maple with a disease resistant Legacy sugar maple in the background right 
Goldspire proved highly susceptible to anthracnose with greater rAAUC intensity and rDAUC defoliation values observed for the former than the latter two cultivars (Table 1).

\section{ANTHRACNOSE ONSET AND DEVELOPMENT OVER TIME}

While anthracnose intensity differed by year and the representative sugar maple cultivar for each resistance class, mean anthracnose-incited defoliation (rDAUC) as indicated by a significant year $\times$ cultivar interaction segregates data by year and cultivar (Table 2). While no differences in anthracnose intensity was noted for any of the representative sugar maple cultivars over the threeyear study period, higher mean rAAUC values were recorded in 2012 and 2013 compared with 2014 (Table 3). Incrementally higher mean rAAUC values were linked with increasing susceptibility of each of the representative cultivars with Fall Fiesta, the

\section{TABLE 1}

Mean relative values for areas under disease progress curves for anthracnose rAAUC (intensity) and rDAUC (defoliation) on selected sugar maple cultivars in Cullman, AL, in 2012, 2013, and 2014.

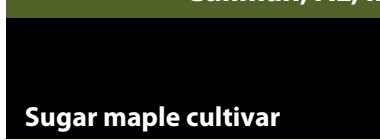

\section{Anthracnose}

Fall Fiesta Intensity Defoliation Resistance

Legacy rAAUCW rDAUC classification

Autumn Faith $1.78 \mathrm{~g}^{\mathrm{y}}$ $2.00 \mathrm{k}$

$1.95 \mathrm{~g}$

$2.34 \mathrm{k}$

$2.59 \mathrm{k}$

Autumn Blush

$2.80 \mathrm{f}$

Steeple (Artis)

$2.00 \mathrm{~g}$

$4.67 \mathrm{jk}$

$2.79 \mathrm{f}$

$6.68 \mathrm{ij}$

$7.80 \mathrm{hi}$

Wright Brothers (Moraine)

$2.19 \mathrm{~g}$

$2.71 \mathrm{f}$

3.32 de

8.86 ghi

Commemoration

Apollo (Barrett Cole)

2.88 ef

10.20 ghi

$11.82 \mathrm{gh}$

$13.00 \mathrm{fg}$

Morton (Crescendo)

$3.47 \mathrm{~d}$

16.43 ef

$3.60 \mathrm{~d}$

19.26 def

Fairview

$4.14 \mathrm{bc}$

21.19 cde

Flax Mill Majesty

Sweet Shadow

Goldspire

Seneca Chief

$3.65 \mathrm{~cd}$

$3.56 \mathrm{~d}$

$22.41 \mathrm{bcd}$

$24.46 \mathrm{bc}$

$4.11 \mathrm{bc}$

$4.56 \mathrm{~b}$

$25.56 \mathrm{bc}$

$5.52 \mathrm{a}$

39.87 a

$\mathrm{R}^{\mathrm{z}}$

R

R

R

MR

MR

MR

$\mathrm{MR}^{\mathrm{z}}$

MR

MR

MS

MS

MS

MS $^{\mathrm{z}}$

MS

S

S

$\mathrm{S}^{\mathrm{Z}}$

${ }^{\mathrm{w}} \mathrm{rAAUC}=$ Relative area under the disease progress curve for anthracnose intensity ratings.

$\mathrm{x}_{\mathrm{rDAUC}}=$ Relative area under the disease progress curve for defoliation attributed to anthracnose.

y Letters following means, when different, indicate significant differences according to Fisher's protected least significant difference test at $P \leq 0.05$.

${ }^{\mathrm{z}}$ Cultivars used as representatives of their respective resistance class.

cultivar representing the resistant cultivar class, having the lowest anthracnose intensity value.

Differences in rDAUC (defoliation) were observed between study years for the susceptible Sugar Queen and moderately resistant Commemoration representative cultivars but not for the moderately susceptible Flax Mill Majesty and resistant Fall Fiesta (Fig. 2). Mean monthly temperature and total monthly rainfall between 1 May and 31 September in each study year is shown (Fig. 3). For the anthracnose susceptible Sugar Queen, higher rDAUC values were recorded under cooler and wetter August and September weather patterns in 2012, while similarly lower levels of premature defoliation were recorded for this cultivar with warmer and drier weather during this same period in the following two years. In contrast, the moderately resistant Commemoration had highest rDAUC values in 2013 when mean temperatures and rainfall were often intermediate to preceding and subsequent years (Fig. 3). For the moderately susceptible Flax Mill Majesty and resistant Fall Fiesta, similar high defoliation levels were noted in each study year regardless of rainfall and temperature patterns.

Disease progress curves of representative cultivars in each resistance class were generated for each study year (Figs. 4A-C). In all study years, lesions on the leaves first appeared between the last week in May and mid-June on anthracnose susceptible cultivars represented by Sugar Queen. In contrast, disease onset was delayed to mid-June to mid-July on the moderately susceptible and moderately resistant cultivars represented by Flax Mill Majesty and Commemoration, respectively. The pattern of disease onset on the resistant cultivar Fall Fiesta, which was similar to Flax Mill Majesty and Commemoration in 2012, was delayed,

\begin{tabular}{|c|c|c|c|c|c|}
\hline \multirow[b]{3}{*}{ Variety } & \multirow{3}{*}{$\begin{array}{l}\text { Resistance } \\
\text { classification }\end{array}$} & $\begin{array}{l}\text { E } 3 \\
C \text { int }\end{array}$ & $\begin{array}{l}\text { sity vo } \\
\text { for e } \\
\text { year }\end{array}$ & $\begin{array}{l}\text { es for } \\
\text { resis } \\
\text { idy p }\end{array}$ & $\begin{array}{l}\text { e } \\
\text { ice } \\
\text { od. }\end{array}$ \\
\hline & & \multicolumn{4}{|c|}{ rAAUC Intensity ${ }^{x}$} \\
\hline & & 2012 & 2013 & 2014 & Mean \\
\hline Fall Fiesta & Resistant & 2.0 & 1.9 & 1.5 & $1.8 \mathrm{~d}^{\mathrm{y}}$ \\
\hline $\begin{array}{l}\text { Commem- } \\
\text { oration }\end{array}$ & $\begin{array}{c}\text { Moderately } \\
\text { resistant }\end{array}$ & 2.7 & 3.3 & 2.1 & $2.7 \mathrm{c}$ \\
\hline $\begin{array}{l}\text { Flax Mill } \\
\text { Majesty }\end{array}$ & $\begin{array}{l}\text { Moderately } \\
\text { susceptible }\end{array}$ & 4.0 & 3.8 & 3.1 & $3.7 \mathrm{~b}$ \\
\hline Sugar Queen & Susceptible & 6.8 & 4.9 & 4.8 & $5.5 \mathrm{a}$ \\
\hline Mean & & $3.9 \mathrm{a}$ & $3.5 \mathrm{a}$ & $2.9 \mathrm{~b}$ & \\
\hline
\end{tabular}

${ }^{\mathrm{x}} \mathrm{rAUC}=$ Relative area under the disease progress curve for anthracnose intensity.

yLetters following means, when different, indicate significant differences according to Fisher's protected least significant difference test at $P \leq 0.05$.

\begin{tabular}{|c|c|c|c|c|c|c|}
\hline \multirow[b]{3}{*}{ Source of variation } & $\begin{array}{l}\text { lear } \\
\text { e rA }\end{array}$ & TABLE 2 & $\begin{array}{l}\text { TABLE } 2 \\
\text { nd represent } \\
\text { (defoliation) }\end{array}$ & & $\begin{array}{l}\text { for each } \\
13 \text {, and }\end{array}$ & ce group on \\
\hline & \multicolumn{3}{|c|}{ rAAUCX Intensity } & \multicolumn{3}{|c|}{ rDAUC' Defoliation } \\
\hline & DF & $F$ value & P value $^{z}$ & DF & $F$ value & P value \\
\hline Year & 2 & 11.64 & $0.0001 * * *$ & 2 & 3.43 & $0.0426^{*}$ \\
\hline Cultivar & 3 & 109.24 & $<0.0001 * * *$ & 3 & 119.72 & $<0.0001 * * *$ \\
\hline
\end{tabular}

$\mathrm{x}_{\text {rAAUC }}=$ Relative area under the disease progress curve for anthracnose intensity.

$\mathrm{y}_{\mathrm{rDAUC}}=$ Relative area under the disease progress curve for defoliation attributed to anthracnose.

${ }^{\mathrm{z}}$ Significance at $0.05,0.01$, and 0.001 levels is indicated by *, **, and ***, respectively. 


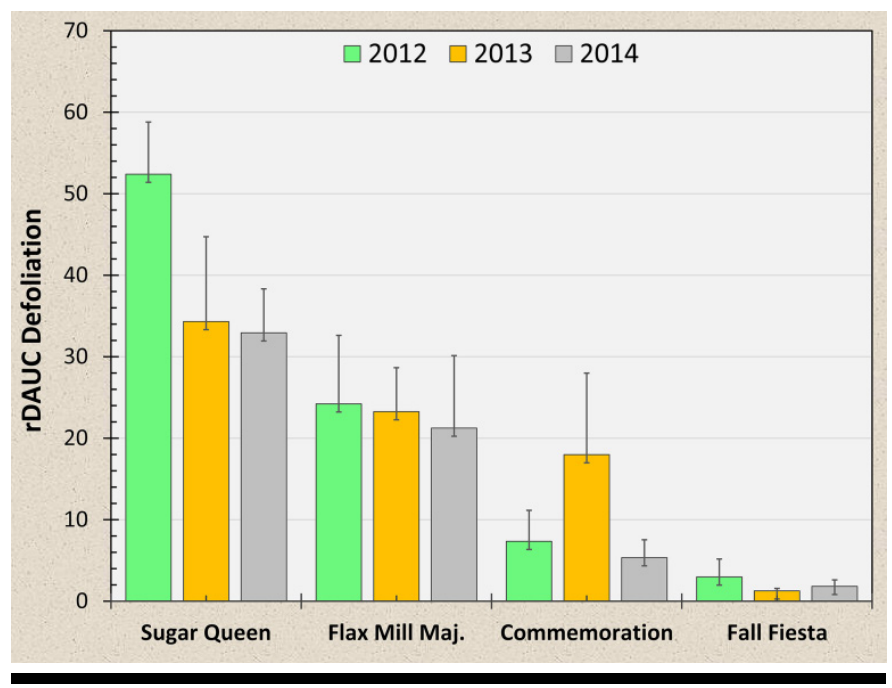

FIGURE 2

Defoliation rDAUC values of representative resistance group sugar maple cultivars by study year. Error bars represent the standard deviation over 3 observations with Commemoration and 5 observations for the remaining cultivars. The rDAUC values equals the relative area under the disease progress curve for defoliation attributed to anthracnose.

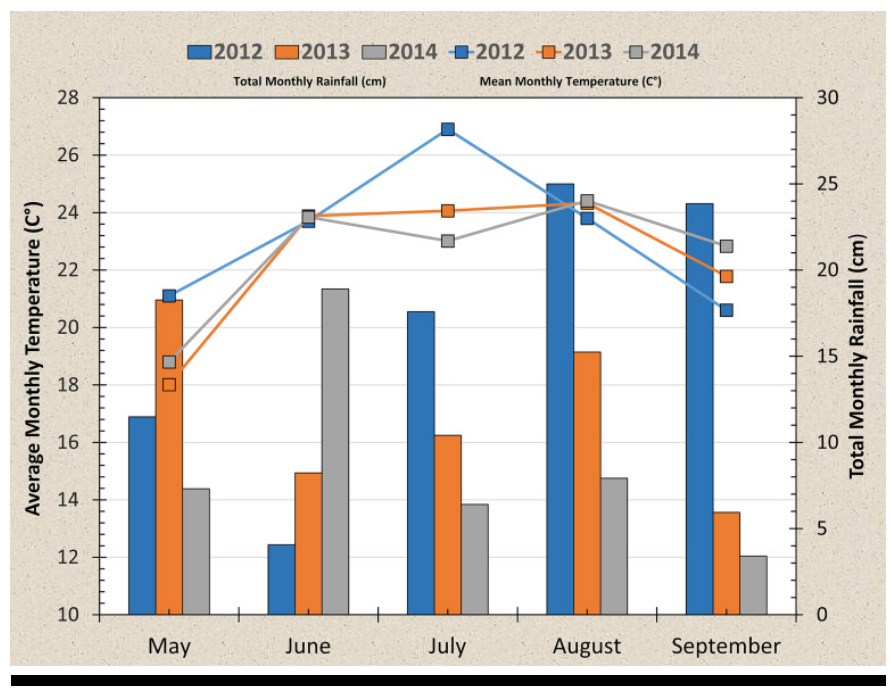

FIGURE 3

Monthly rainfall totals and mean high temperatures for May through September in 2012, 2013, and 2014 at the study site in Cullman, AL.
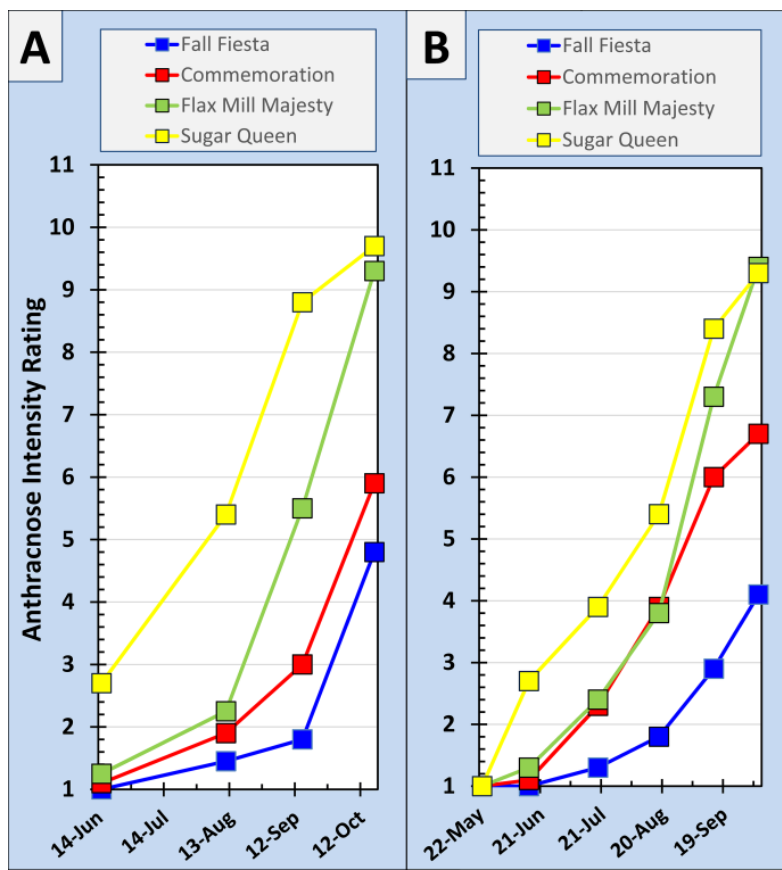

particularly in 2014 when symptoms were not observed until late August. Disease development, as indicated by the increasing number of symptomatic leaves and premature defoliation, was greatly accelerated on the susceptible Sugar Queen and moderately susceptible Flax Mill Majesty compared with the moderately resistant and resistant cultivars Commemoration and Fall Fiesta, respectively, with the latter having substantially lower final anthracnose intensity ratings than the former in only 2013.

Anthracnose-incited defoliation was first observed on the susceptible Sugar Queen by mid-July compared with mid-August for the moderately susceptible Flax Mill Majesty, mid-August to mid-September for the moderately resistant Commemoration, and mid-October for the resistant Fall Fiesta (Fig. 5 A-C). A rapid increase in premature defoliation was noted by mid-August and mid-September for the susceptible and moderately susceptible sugar maple cultivars, respectively. While the anthracnose resistant Fall Fiesta (Fig. 6A) and Legacy (Fig. 6B) sugar maples suffered $20 \%$ or less defoliation by mid-October in all study years, defoliation levels on the moderately resistant sugar maple Commemoration (Fig. 6C) and Green Mountain (Fig. 6D) did not reach the 40 to $50 \%$ level until after mid-September in two of three study years. The moderately susceptible Flax Mill Majesty (Fig. 6E) and Morton (Fig. 6F) along with the susceptible Sugar Queen (Fig. 6G) and Gold Spire (Fig. 6H) sugar maple cultivars were almost completely defoliated by mid-October and midSeptember, respectively. 


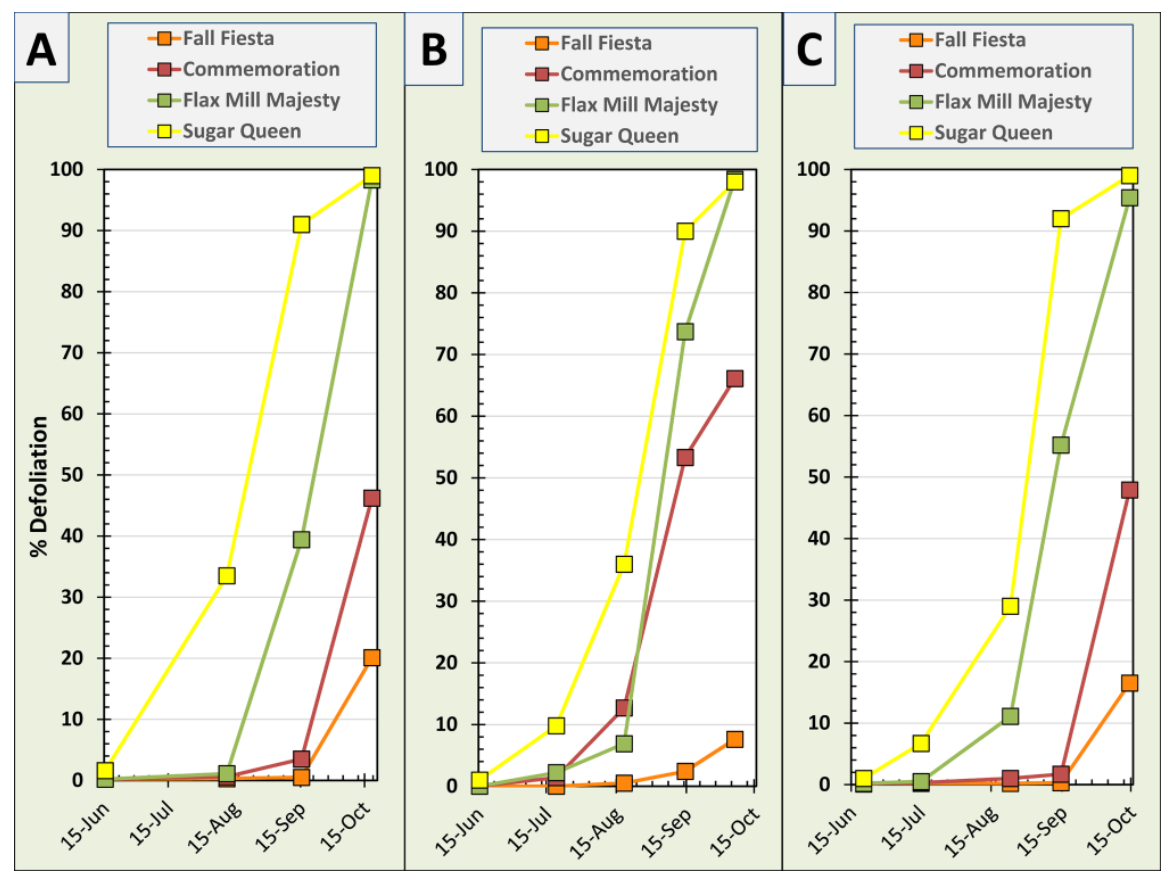

FIGURE 5

Defoliation on selected sugar maple cultivars segregated into anthracnose resistance classification in (A) 2012, (B) 2013, and (C) 2014 in Cullman, AL.

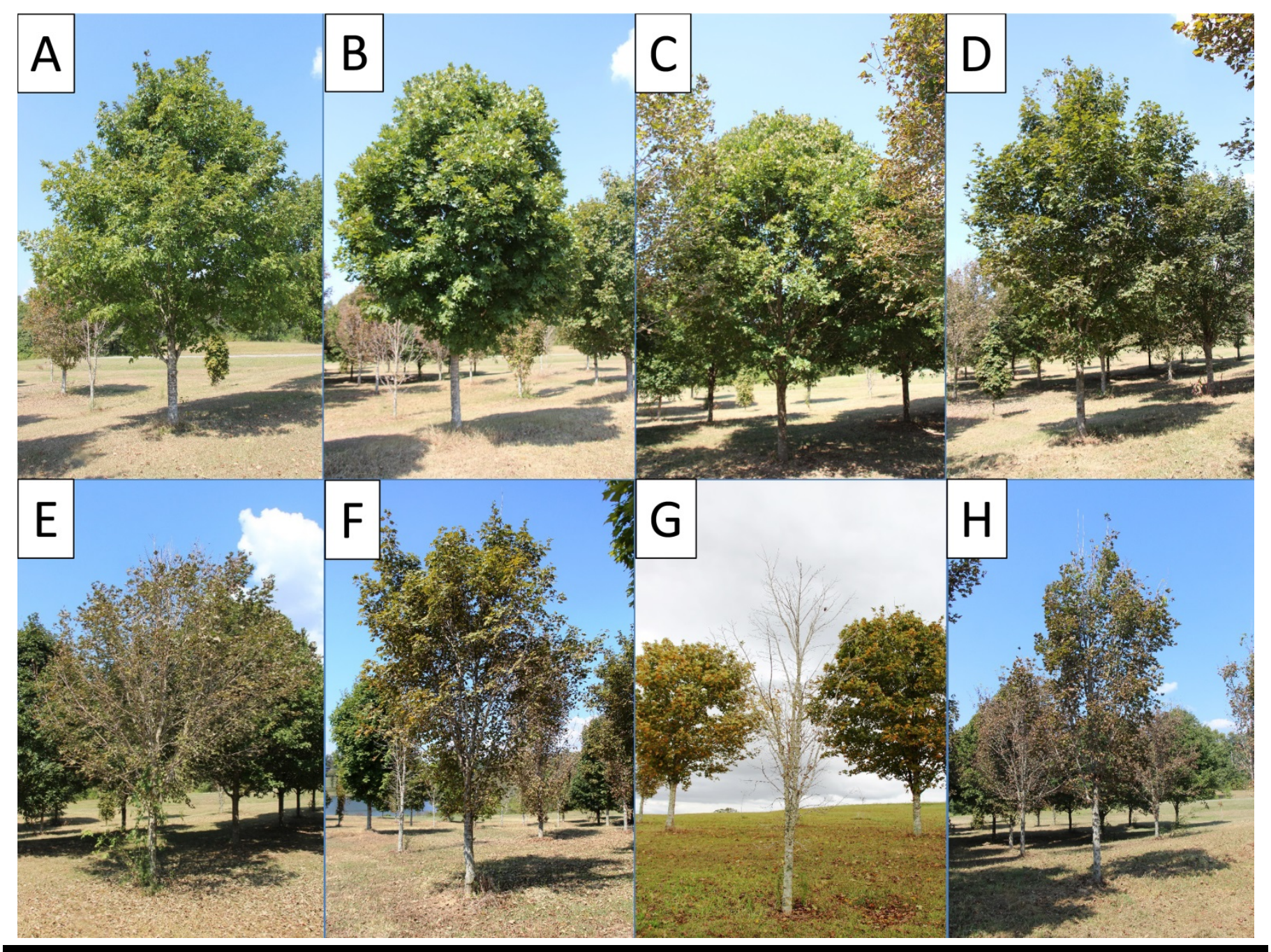

FIGURE 6

Sugar maple cultivars (A) Fall Fiesta, (B) Legacy, (C) Commemoration, (D) Green Mountain, (E) Flax Mill Majesty, (F) Morton, (G) Sugar Queen, and (H) Gold Spire in Cullman, AL. All photographs were taken on 18 September 2014 except for that of Sugar Queen, which was taken on 13 October 2014 , and bracketed by two Green Mountain sugar maples (background). 


\section{CONCLUSIONS}

Anthracnose symptoms observed on multiple sugar maple cultivars in this study were similar to those attributed to an unknown Discula sp. by Sinclair and Lyon (2005). Depending on the level of resistance, anthracnose onset had occurred by midJune for susceptible cultivars compared with July or August for resistant cultivars. Noticeable defoliation was observed on anthracnose-susceptible and -resistant cultivars by mid-July and mid-October, respectively. Kessler (1984) had also observed a seasonal pattern of anthracnose development in black walnut (Juglans nigra L.) over a four-year period, which culminated with complete tree defoliation by early August, as was observed here for the anthracnose-susceptible sugar maple cultivars. While anthracnose clearly reduces the aesthetic value of sugar maple, this study was not designed to define disease impact on tree health and vigor. However, reduced trunk diameter and shoot growth of field-grown flowering dogwood (Cornus florida L.) was associated with the increasing incidence of leaf necrosis and premature defoliation attributed to Cercospora leaf spot and spot anthracnose (Hagan et al. 2008), which suggests that severe anthracnose outbreaks on susceptible and moderately susceptible sugar maple cultivars may suppress tree growth. Berry (1981) also reported that the premature defoliation attributed to anthracnose slows the growth of walnut (Juglans) species.

Weather, as represented by mean monthly temperature and total rainfall during the disease assessment period in each study year, had a varied impact on each sugar maple cultivar in each resistance group. When compared with warmer and drier weather in 2013 and to a lesser extent 2014, cooler and wetter summer weather patterns in 2012 were associated with greater anthracnose intensity and defoliation in the anthracnose susceptible Sugar Queen but not the moderately susceptible cultivar Flax Mill Majesty, resistant Fall Fiesta, and moderately resistant Commemoration with the latter suffering greater damage under hotter and drier conditions in 2013. Previously, Neely and Himelick (1963) noted that temperature but not rainfall significantly impacted the development of Apiognomonia veneta (Sacc. \& Speg.) Höhn.incited anthracnose on sycamore (Platanus occidentalis L.). In contrast, wet growing seasons along with extended periods of leaf wetness are associated with epiphytotic outbreaks of Gnomonia leptostyla (Fr.) Ces. \& De Not.-incited anthracnose of English $(J$. regia L.) (Belisario 2002) and black walnut (Kessler 1984). Additional study is need to better define the interaction of weather and cultivar resistance on the onset and intensification of anthracnose in sugar maple.

On the basis of growth rate, leaf area, petiole length, chlorophyll content, and sensitivity to Japanese beetle feeding injury to the leaves, Blackwood (2006) rated Autumn Blush, Bonfire, Green Mountain, and Sugar Queen as top cultivars, while Apollo, Commemoration, Fairview, Legacy, and Morton gave the poorest performance. With the appearance of the leaf spotting and premature defoliation associated with anthracnose, cultivar reaction to this disease takes precedence in determining the long-term landscape value of sugar maple cultivars and not the above criteria listed by Blackwood (2006). The anthracnose susceptible cultivars Goldspire, Seneca Chief, and Sugar Queen and moderately susceptible cultivars Endowment, Fairview, Flax Mill Majesty, Morton, and Sweet Shadow often were defoliated by mid-October, thereby eliminating the fall color display for which sugar maple are renowned and rendering them unsuitable for landscape use (Dirr 1998). In contrast, the resistant cultivars Autumn Blush, Autumn Faith, Fall Fiesta, and Legacy, which suffered minimal defoliation and exhibited desirable fall color, would be excellent choices for amenity and commercial landscapes in the Mid- and Upper South.

\section{LITERATURE CITED}

Belisario, A. 2002. Anthracnose. Pages 77-78 in: Compendium of Nut Crop Diseases. B. L. Teviotdale, T. J. Michailides, and J. W. Pscheidt, eds. American Phytopathological Society, St. Paul, MN.

Berry, F. H. 1981. Walnut anthracnose. USDA-FS, Forest Insect and Disease Leaflet 85. http://na.fs.fed.us/spfo/pubs/fidls/walnut_anthr/wal_anthr.htm

Blackwood, K. R. 2006. Performance of sugar maple taxa (Acer saccharum Marsh.) in North Alabama. MS Thesis. Auburn University, AL. https://etd.auburn.edu/bitstream/handle/10415/600/BLACKWOOD_KEN NETH 55.pdf? sequence $=1 \&$ ts $=1457177994847$

Chiteka, Z. A., Gorbet, D. W., Shokes, F. M., Kucharek, T. A., and Knauft, D. A. 1988. Components of resistance to late leaf spot in peanut. 1. Levels of variability-implications for selection. Peanut Sci. 15:25-30. http://www.peanutscience.com/doi/pdf/10.3146/i0095-3679-15-1-8

Dirr, M. A. 1998. Manual of Woody Landscape Plants, 5th Ed. Stipes Publ. Co., Champaign, IL.

Godman, R. M., Yawney, H. W., and Hobbs, C. H. 1990. Silvics of North America: Acer saccharum Marsh. Pages 194-216 in: 2. Hardwoods. R. M. Burns and B. H. Honkala, eds. Agriculture Handbook 654, Vol. 2. USDAFS, Washington, DC. http://www.na.fs.fed.us/spfo/pubs/silvics manual/table of contents.htm

Hagan, A. K., Akridge, J. R., and Bowen, K. L. 2008. Nitrogen rate and flowering dogwood. 1. Influence of nitrogen fertilization rate on the occurrence of spot anthracnose, powdery mildew, and Cercospora leaf spot on tree growth. J. Environ. Hort. 26:197-203.

Hartman, J. R. 1996. Anthracnose diseases of shade trees. Kentucky Coop. Ext. Ser. Circ. PPA-17, Univ. of Kentucky, Lexington. http://www2.ca.uky.edu/agcomm/pubs/ppa/ppa17/ppa17.pdf

Howse, G. M., and Applejohn, M. J. 1990. Forest insect and disease conditions in Ontario. For. Can. Great Lakes For. Cent. Surv. Bull. Fall. 1990. http://cfs.nrcan.gc.ca/pubwarehouse/pdfs/33255.pdf

Kessler, K. J., Jr. 1984. Similarity of annual anthracnose epidemics on young Juglans nigra plantations from 1978 to 1982. Plant Dis. 68:571-573. http://www.apsnet.org/publications/PlantDisease/BackIssues/Documents/ 1984Articles/PlantDisease68n07 571.pdf

Li, Y., Culbreath, A. K., Chen, C. Y., Knapp, S. J., Holbrook, C. C., and Guo, B. 2012. Variability in field response of peanut genotypes from the U.S. and China to tomato spotted wilt virus and leaf spots. Peanut Sci. 39:3037.

Nash, B. L., Stanosz, G. R., Taylor, G., and Davis, D. D. 1994. Discula campestris infection of sugar maple leaves associated with pear thrips injury. Plant Dis. 78:285-289.

http://www.apsnet.org/publications/PlantDisease/BackIssues/Documents/ 1994Articles/PlantDisease78n03 285.pdf

Neely, D., and Himelick, E. B. 1963. Temperature and sycamore anthracnose severity. Plant Dis. Reptr. 47:171-175.

Shaner, G., and Finney, R. E. 1977. The effect of nitrogen fertilization on the expression of slow-mildewing resistance in wheat. Phytopathology 67:1051-1056.

http://www.apsnet.org/publications/phytopathology/backissues/Document s/1977Articles/Phyto67n08_1051.pdf

Sinclair, W. A., and Lyon, H. H. 2005. Diseases of Trees and Shrubs, 2nd Ed., Cornell Univ. Press, Ithaca, NY.

Sogonov, M. V., Castlebury, L. A., Rossman, A. Y., and White, J. F. 2007. The type species of Apiognomonia, A. veneta, with its Discula anamorph is distinct from A. errabunda. Mycological Res. 111-693-709. doi:10.1016/j.mycres.2007.03.013

Stanosz, G. R. 1993. Symptoms, association, and pathogenicity of Discula campestris, a cause of sugar maple seedling anthracnose. Plant Dis. 77:1022-1026. http://www.apsnet.org/publications/plantdisease/backissues/Documents/1 993Articles/PlantDisease77n10_1022.pdf

Stanosz, G. R. 1994. Sugar maple anthracnose caused by Discula campestris in Wisconsin. Plant Dis. 78:1217.

Zhang, L., Oswald, B., and Green, T. H. 1999. Relationship between over story species and community classification of the Sipsey Wilderness, Alabama. Forest Ecol. Manag. 114:377-383. 